\title{
Ayçiçeği pektiniyle enkapsüle edilen hidrofilik ve lipofilik kırmızı renklendiricilerin hidrojel ve emülsiyon hidrojellerindeki stabilitesi
}

\section{Encapsulation and stability of hydrophilic and lipophilic red colorants in sunflower pectin hydrogels and particle filled gels}

\section{Özgenur COŞKUN' (i), ibrahim GÜLSEREN* (iD)}

1'istanbul Sabahattin Zaim Üniversitesi (izÜ), Gıda Mühendisliği Bölümü, Halkalı Kampüsü, 34303, Küçükçekmece-İstanbul

To cite this article:

Coşkun, Ö. \& Gülseren, ì., (2018). Ayçiçeği pektiniyle enkapsüle edilen hidrofilik ve lipofilik kırmızı renklendiricilerin hidrojel ve emülsiyon hidrojellerindeki stabilitesi. Harran Tarım ve Gıda Bilimleri Dergisi, 22(3): 403-412.

DOI: 10.29050/harranziraat.3965 02

Address for Correspondence: İbrahim GÜLSEREN

e-mail:

ibrahim.gulseren@izu.edu.tr

Received Date:

19.02.2018

Accepted Date:

11.07.2018

(c) Copyright 2018 by Harran University Faculty of Agriculture. Available on-line at www.dergipark.gov.tr/harranziraat

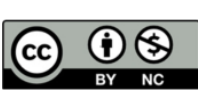

öz

Hidrojeller ve parçacık içeren hidrojeller (emülsiyon jelleri), hidrofilik ve lipofilik boyaların enkapsülasyonunda kullanıma uygunluk arz eden enkapsülasyon sistemleridir. Bu çalışmada, ayçiçeği pektini bazlı hidrojellerde ve emülsiyon hidrojellerinde sırasıyla hidrofilik (Ponceau S) ve lipofilik kırmızı (metil kırmızısı) model boyar maddelerin stabilize edilmesi incelenmiştir. Bütün deneylerde, pektin hidrojellerinin kırmızı boyar maddeleri enkapsüle etme kabiliyeti bulgulanmıştır. Hidrofilik Ponceau S taşıyan hidrojellere kıyasla parçacık içeren emülsiyon jellerinde daha yüksek miktarlarda metil kırmızısı taşınması mümkün olmuştur. Her iki durumda da, boyar maddelerin jel matrislerinden salınımı 2 hafta boyunca izlenmiştir. Enkapsülasyon veriminin (\%EV) pektin konsantrasyonunun ve boyar maddenin kimyasal özelliklerinin bir fonksiyonu olduğu anlaşılmıştır. Boya salınım miktarları genellikle <\%10 olarak gerçekleştiği için enkapsülasyon sistemleri kararlı olarak nitelendirilmiştir. Dolayısıyla bu çalışmada hem boyaların etkili bir yöntemle stabilizasyonu, hem de tarımsal bir yan ürünümüzün değerlendirilmesi söz konusudur.

Anahtar Kelimeler: Pektin hidrojelleri, Emülsiyon jelleri, Boyar madde enkapsülasyonu, Depolama kararlıı̆ı, Atıkların değerlendirilmesi.

\section{ABSTRACT}

Hydrogels and particle filled gels are promising tools in the encapsulation of hydrophilic and lipophilic dyes. Here, we made an attempt to stabilize hydrophilic (Ponceau S) and lipophilic red (methyl red) colorants in sunflower pectin based hydrogels and particle filled gels, respectively. In all cases, the red colorant encapsulation characteristics of pectin hydrogels was significant. A higher extent of methyl red was incorporated into the particle filled gels compared to Ponceau $S$ bearing hydrogels. In both cases, the extent of release was monitored for 2 weeks. The encapsulation efficiency was a function of pectin concentration and the chemical properties of the dye molecules. The encapsulation systems were regarded as stable since the extent of dye release was $<10 \%$ in most cases. Therefore, 
in this study, both the stabilization of the dyes with an effective method and the valorization of the agricultural by-products are investigated.

Key Words: Pectin hydrogels, Emulsion gels, Dye encapsulation, Storage stability, Waste valorization.

\section{Giriş}

Pektinler, bitki hücre duvarlarında yaygın olarak bulunan, esas olarak D-galakturonik asit kalıntılarından oluşan iyonik heteropolisakkaritlerdir. Metil esterifikasyon özellikleri, pektinlerin jelleşme davranışlarını büyük ölçüde belirleyen özellikleridir. Düşük metoksilli pektinin negatif yüklü karboksil grupları, kalsiyum iyonlarıyla çapraz bağlar oluşturur ve pektinin iyonotropik jelleşmesine neden olur (Sriamornsak ve ark., 2005). Düşük metoksilli pektinler ("low methoxy pectin", LMP) genellikle yüksek metoksilli pektinlerden ("high methoxyl pectin", HMP) asit, alkali veya enzimatik işlemlerle üretilmektedirler. Öte yandan, HMP kaynaklarına oranla LMP'lerin doğal kaynakları daha azdır (Iglesias ve Lozano, 2004). Bu anlamda doğal kaynaklardan doğrudan üretilen ya da izole edilen LMP ürünlerine gereksinim bulunmaktadır.

Ayçiçeği kafaları, ayçiçeği yağı üretiminin yan ürünlerindendir. Çekirdekleri ayıklanmış ayçiçeği kafalarından düşük metoksilli pektin (LMP) izolasyonu ve bu prosesin optimize edilmesi alanlarında literatürde çalışmalar bulunmaktadır (Shi ve ark., 1996). Bu ürün, gıda formülasyonlarında güvenle kullanılabilme potansiyeline sahiptir. Çekirdekleri ayıklanmış kafalar, LMP'lerin önemli bir kaynağını oluşturmaktadır (ağırlıkça \%15-25 pektin) (Shi ve ark., 1996). Ayçiçeği pektininin bazı özellikleri (örneğin, molekül ağırlık dağılımı: 30.000-500.000 g/mol; GalA içeriği: \% 70-90; metoksilasyon derecesi: \% 10-40, genelde yaklaşık\% 12; ve asetillenme derecesi: \% 2-4) halihazırda bilinmektedir (Iglesias ve Lozano, 2004; Miyamoto ve Chang, 1992; Sahari ve ark., 2003). Kalsiyum pektat jellerinin, model ilaçların kolona teslimatında kullanımı ile de ilgili çalışmalar bulunmaktadır (Sriamornsak ve ark., 2005; Rubinstein ve ark., 1993; Ashford ve ark., 1994). Grubumuzun yaptığı çalışmalarda da, kanser ilaçlarının enkapsüle ve stabilize edilmesinde de ayçiçeği pektininin etkili olarak kullanılabileceği ve bu biçimde kullanılan ilaçların kolon kanseri hücrelerinin gelişimini etkili bir biçimde azaltabileceği bulgulanmıştır (Çakır ve Gülseren, 2017).

Enkapsülasyon, aktif bileşiklerin veya ürünlerin stabilitesini arttırmak için teknik veya biyolojik açıdan aktif bileşiklerin belirli bir matris veya membran içinde bölümlendirilmesi, makro, mikro, nano vs. kompartmanlara ayrılması (Chan ve ark., 2009) süreci olarak tanımlanır. Enkapsülasyon matrislerinin koruyucu rolleri; aktif bileşiklerin geçirebileceği oksidatif stresler ya da gıda işleme ile insan vücudundaki sindirim sırasında ortaya çıkan stresler dolayısıyla bozunuma uğramasını önleyebilir. Başarılı enkapsülasyon sistemleri, gıdalardaki ve diğer tüketici ürünlerinde aktif bileşiklerin kararlılığını ve aktivitesini koruyabilmekte ve uzatabilmektedir.

Aktif maddelerin polaritesi, kullanılması gerekli olan enkapsülasyon sistemlerinin özelliklerini değiştirebilmektedir. Hidrojeller, makromoleküler kompleksler, protein nanoparçacıkları, yağda su emülsiyonları gibi 
enkapsülasyon sistemleri hidrofilik malzemelerin enkapsülasyonu için uygunken suda yă̆ emülsiyonları, katı lipid nanoparçacıkları gibi sistemler de genellikle lipofilik aktif bileşikler için yararlıdır (Mcclements ve ark., 2007; McClements ve ark., 2009). Her iki durumda da, enkapsülasyon uygulamalarında doğal ve yenilenebilir biyopolimerlerin kullanılması yoğun olarak incelenen bir çalışma alanıdır (Wang ve ark., 2006).

Kırmızı boyar maddeler, gıda işlemede en çok kullanılan renklendirme maddeleri arasındadır. Günümüzde yeni ve kararlı kırmızı renklendiricilerin üretilmesi amacıyla çeşitli bitki, mantar ve yosun kaynakları araştırılmaktadır (Arad ve Yaron, 1992; Dufosse ve ark., 2014; Sowbhagya ve Chitra, 2010).

Enkapsülasyon, renklendiricilerin stabilitesini arttırmak için de uygulanan bir tekniktir (Zhang ve Zhang, 2013). Bu çalışmada, kalsiyum pektat hidrojelleri ve emülsiyon damlacıkları içeren kalsiyum pektat hidrojelleri kullanılarak hidrofilik ve hidrofobik model kırmızı renklendiricilerin enkapsülasyonu yapılmıştır. Ponceau $\mathrm{S}$, biyokimyasal analizlerde yaygın olarak kullanılan kırmızı renkli, suda çözünür bir boyadır (Al-Amoudi ve ark., 2015). Metil kırmızısı ise, çeşitli yağlar ve alkollerde çözünen bir boyar maddedir (Clarke ve Kirner, 1941). Ticari olarak yüksek saflıklarda piyasada bulunmaları ve sabit renk yoğunluğu performansı göstererek kolayca çözeltilerdeki konsantrasyonlarının belirlenebilmeleri dolayısıyla model sistemler olarak kullanıımaları bu çalışma için tarafımızca uygun bulunmuştur.

Son dönemlerde hidrojellerin, doğal dokulara (Peppas ve Langer, 1994) ve endüstriyel ürünlere (Anthony ve ark., 2016) uyumluluğunun gösterilmiş olmasının yanında; bu sistemlerde numune tekstürünün ve aktif madde salınımının kontrol edilebilirliğinin de yüksek olması dolayısıyla hidrojeller teknik ve biyolojik aktivite gösteren aktif maddelerin stabilizasyonu için uygun sistemler olarak değerlendirilmişlerdir (Hoffman, 2002). Lipofilik moleküllerin stabilize edilmesi için kullanılabilecek olan emülsiyon hidrojelleri gıda sınıfı bileşenlerden üretilebilmektedir (Matalanis ve ark., 2011). Hidrojellerin bileşimine bağlı olarak, jel boncuklarından ("bead") yağ damlacıklarının salınım hızları, boncukların şişmesi ya da parçalanması hususları düzenlenebilmektedir (Filippidi ve ark., 2014). Buna ek olarak, yağ damlacıkları ile hidrojel matrisleri arasındaki etkileşimler, değişken koşullar altında matrislerden salınmayı geciktirmek veya hızlandırmak için modüle edilebilir (Zeeb ve ark., 2012). Sonuç olarak, hidrojellerin ve emülsiyon hidrojellerinin tasarım ve kontrol kolaylığı ve gıda sınıfı bileşenlerle imal edilebilmeleri yeni formülasyonlarda yararlı olabilmektedir.

Bu çalışmanın amacı ayçiçeği pektini bazlı hidrojeller ve emülsiyon jelleri kullanarak hidrofilik ve hidrofobik kırmızı renklendiricileri enkapsüle ve stabilize etmektir. Her iki sistem de enkapsülasyon verimi ve salınım özellikleri açısından incelenmiştir. Böylelikle hem boyaların etkili bir yöntemle stabilizasyonu, hem de tarımsal bir yan ürünümüzün değerlendirilmesi söz konusudur. Basit model sistemler kullanılarak edinilecek bulgular, bitki ekstraktları (örneğin, boyar madde ve/veya polifenol karışımları, şekerler içeren sistemler vb.) gibi daha karmaşık ve çok bileşenli maddelerin enkapsülasyon özellikleri hakkındaki bilgilerimizi geliştirme potansiyeli taşımaktadır. 
Materyal ve Metot

\section{Reaktifler ve kimyasallar}

Metil kırmızısı (250198), Ponceau S (141194), Tween 20 (P1379) ve soya yağı (S7381) Sigma Chemical Company (St. Louis, MO, ABD) şirketinden alınmıştır. Diğer tüm kimyasallar reaktif sınıfı olarak değerlendirilebilecek niteliktedir.

\section{Ayçiçeği pektininin hazırlanması}

Ayçiçeği (Helianthus annuus L.) kafaları Tekirdağ'da yerel bir çiftlikten toplandı. Pektin izolasyonu, Shi vd. (1996) tarafından açıklanan yönteme uygun olarak yürütüldü. Vakumlu kurutmadan ve öğütmeden sonra ayçiçeği kafaları, 28:1 (çözücü:çözünen) oranı ile 25 dakika boyunca bir alkali çözelti ( $\mathrm{pH} 7.5,16^{\circ} \mathrm{C}$ ) ile muamele edildi (Shi ve ark., 1996). Karışım süzüldü ve filtre keki, sodyum heksametafosfat (SHMP) çözeltisi (1:25 kek:SHMP çözeltisi oranı; $75^{\circ} \mathrm{C}^{\prime}$ de 1 saat) ile muamele edildi. Ortamın $\mathrm{pH}$ değeri, fosforik asit ile $\mathrm{pH} 3.5^{\prime}$ e ayarlandı. Süzüntü, $1 \mathrm{M}$ nitrik asit $\left(5^{\circ} \mathrm{C}, 1: 5\right.$ asit çözeltisi:filtrat oranı) kullanılarak çökeltildi. Böylece oluşturulan pektin jeli, son üründeki mineral ve asit içeriğini düşürmek amacıyla etanolik çözeltiler $\left(700 \mathrm{ml}\right.$ etanol. $\left.\mathrm{L}^{-1}\right)$ ile $6 \mathrm{kez}$ yıkandı (jel:solvent oranı 1:2) ve pektinin renk özellikleri iyileştirildi. Yıkanan jel, vakum fırınında kurutuldu $\left(55^{\circ} \mathrm{C}, 16\right.$ saat). Kurutulan pektin numuneleri öğütüldü ve kullanıma kadar $-20^{\circ} \mathrm{C}^{\prime}$ de tutuldu.

\section{Pektin hidrojellerinin ve emülsiyon} hidrojellerinin hazırlanması

Hidrofilik boyanın enkapsülasyonu için düşük metoksilli ayçiçeği pektini suda (\% 0.2 veya \% 0.4 pektin) çözündürülerek kalsiyum pektinat jel boncukları yapımı için hazırlandı $\left(50^{\circ} \mathrm{C}, 1\right.$ saat). Pektin dispersiyonları soğutulduktan sonra; dispersiyonlar ve değişen boya konsantrasyonlarında Ponceau S çözeltileri (50-500 ppm) hacmen 1:1 oranında karıştırıldı. Bu karışımdan alınan $2 \mathrm{ml}$ alikotlar Titromatic $1 S$ titratörü (Crison Instruments S.A. Barcelona, İspanya) ile 30 saniye içinde $100 \mathrm{ml}$ $0.2 \mathrm{M} \mathrm{CaCl}{ }_{2}$ çözeltilerine titre edildi. Jel boncuklarının bütünlüğünü ve sağlamlığını sağlamak için bu karışım oda sıcaklığında 15 dakika karıştırıldı (100 devir.dakika $\left.{ }^{-1}\right)$. Enkapsüle edilen boya miktarını ölçmek için sıvı fazdan periyodik olarak numuneler alındı. Alınan numunelerdeki çözünmeyen maddeler 0.45 ? $\mathrm{m}$ PVDF membran filtreleriyle uzaklaştırıldı ve boya salınım hızı, 520 nm'de numunelerin absorbans değerleri (Optima SB3000 UV / VIS spektrofotometre) takip edilerek 2 hafta boyunca kaydedildi.

Benzer şekilde, lipofilik boyanın enkapsülasyonu için pektin dispersiyonları $50^{\circ} \mathrm{C}^{\prime}$ de hazırlandı (\% 0.2 veya \% 0.4 pektin). Metil kırmızısı (100 veya 500 ppm) soya yağı içinde çözüldü. Daha sonra, su içinde yağ emülsiyonlarının hazırlanması için, emülgatör olarak Tween 20 (\% $\left.\begin{array}{ll}\%\end{array}\right)$ kullanıldı. Bütün numunelerde yağ fazının (dispers faz) konsantrasyonu \%10 olarak uygulandı. Emülsifikasyon, maksimum cihaz gücü ve kesikli modda (\% 50) 4 dakika boyunca bir ultrasonik homojenizatör (Hielscher Model UP200Ht) kullanılarak gerçekleştirildi. Böylece oluşturulan emülsiyonlardan alınan $2 \mathrm{ml}$ alikotlar, Titromatic $1 S$ titratörü ile 30 saniye içinde 100 $\mathrm{ml} 0.2 \mathrm{M} \mathrm{CaCl}_{2}$ çözeltilerine titre edildi ve yine jel boncuklarının bütünlüğünü ve sağlamlığını sağlamak için karıştırmaya tabi tutuldu. Boyanın salınım hızı, $410 \mathrm{~nm}$ 'de gerçekleşen numune absorbansına bağlı olarak 2 hafta boyunca izlendi. Bu durumda, ışık saçılması nedeniyle yağ damlacıklarının varlığının sebep olduğu absorbans da dikkate alındı. Bütün numunelere bakteriostatik olarak \% 0.02 sodyum azid eklendi. 
Enkapsülasyon veriminin tayini

Hidrofilik boyanın enkapsülasyon verimi

Ponceau S'nin enkapsülasyon verimini (\% EV) saptamak için, sulu fazda kalan boya konsantrasyonu, 520 nm'de hazırlanan referans eğriye kıyasla hesaplandı. Bu değere bağlı olarak boyanın enkapsülasyon verimi belirlendi:

$\% E V=100-\left(\frac{\text { Sulu çözeltideki boya konsantrasyonu }}{\% 0 E V^{\prime} \text { de sulu fazda bulunabilecek maksimum boya konsantrasyonu }} x 100\right)$

Lipofilik boyanın enkapsülasyon verimi (\% EV)

Metil kırmızısının \% enkapsülasyon verimini (\% EV) belirlemek için, önce metil kırmızısı içermeyen emülsiyon jelleri hazırlandı. $410 \mathrm{~nm}$ 'deki absorbans, zamanın bir fonksiyonu olarak tespit edildi ve boya içermeyen damlacıkların salınımına bağlı olarak absorbans kaydedildi. İkinci olarak, metil kırmızısı referans çözeltileri soya yağı içerisinde hazırlandı ve farklı boya konsantrasyonlarına karşılık gelen referans eğri çizildi. Bu işlem, soya yağındaki metil kırmızısı molekülünün molar absorpsiyon katsayısının belirlenmesini sağladı. Son olarak, kırmızı boya içeren emülsiyon jellerinde absorbans değerlerinin zamana bağlılığı göz önüne alınarak, kırmızı boyanın enkapsülasyon verimi aşağıdaki denklem yardımıyla belirlendi:

$$
\% E V=100-\left(\frac{\text { Damlacılardaki boya konsantrasyonu }}{\% 0 \text { EV'de sürekli fazdaki bulunabilecek maksimum boya konsantrasyonu }} \times 100\right)
$$

\section{istatistiksel analiz}

Bu çalışmada yürütülen tüm deneyler en az 3 paralel ve 2 tekerrürlü olarak tamamlanmıştır. Deney sonuçları, ortalama değer \pm standart sapma analizleri üzerinden değerlendirilmiştir. Numuneler arasındaki farklılıklar istatistiksel farklılık esasına $(p<0.05)$ bağlı olarak ANOVA testleri ile belirlenmiştir.

\section{Araştırma Bulguları ve Tartışma}

\section{Hidrofilik boyanın enkapsülasyon verimi}

Suda çözünür Ponceau $\mathrm{S}$ kırmızı boyar maddesi (50-500 ppm), ayçiçeği pektini sulu dispersiyonlarıyla karıştırıldı ve jel boncuklarının oluşumunu sağlamak için $\mathrm{CaCl}_{2}$ çözeltilerine $(0.2 \mathrm{M})$ kontrollü bir biçimde titre edildi. Hidrojel boncuklarında enkapsüle edilmiş boya miktarı belirlendi ve enkapsülasyon kararlılığı 14 gün boyunca izlendi (Şekil 1A-D). Her iki pektin konsantrasyonunda (\%0.2 ve 0.4 pektin) deneyin başlangıcında nispeten yüksek bir enkapsülasyon etkinliği gözlenirken depolama süresi boyunca \% 0.2 pektin numuneleri için belirli bir oranda salınım gerçekleşti (Şekil 1A). Örneğin, $t=0$ 'da 100 ppm boya eklenen $\% 0.4$ ve \% 0.2 pektin hidrojelleri için \%EV değerleri sırasıyla \%43 ve \%26 iken, 2 haftalık depolama sonrasında nihai \%EV değeri \% 45 ve \% 21 olarak bulundu (Şekil 1B). Diğer numuneler için de benzer trendler gözlendi (Şekil 1C ve 1D). Bütün deneylerde, \%0.4 pektin ihtiva eden hidrojeller, yapılarında daha küçük gözeneklerin bulunması nedeniyle (örneğin, bkz. Glibowski, 2009) kırmızı boya salınımına karşı daha dirençli olarak değerlendirildi. Bazı durumlarda, \%EV değeri zamanla hafifçe yükseldi. Bu durum boya molekülleri ve pektin matrisleri 
arasındaki dengenin zaman içinde oluştuğu anlamına gelebilmektedir (geri difüzyon). Enkapsülasyon verimi boya:pektin oranına bağlı olarak genellikle \% 45-85 arasında değişti.

Enkapsüle edilen boya miktarı aynı zamanda boya:pektin oranının (mg/mg) fonksiyonu olarak değerlendirildi ve bu değerlerin zamana bağlı değişimi Çizelge 1 'de özetlendi. Hidrojel boncuklarında enkapsüle edilmiş boya miktarı, boya konsantrasyonu ile arttı. Enkapsüle edilen miktar depolama süresiyle zayıf bir şekilde ilişkiliydi; bu durum da sistemin nispeten kararlı olduğu anlamına geldi. Daha düşük boya konsantrasyonlarında, pektin konsantrasyonu enkapsüle edilmiş boya miktarını belirgin olarak etkilerken yüksek boya konsantrasyonlarında pektin konsantrasyonunun etkisi önemli ölçüde azaldı. Bu gözlem, fazlar arasındaki (diğer bir deyişle, boncuklar ve sulu faz arasındaki) dağılıma bağlanabilir. Bütün durumlarda, çözünür boyanın önemli bir kısmı sulu fazda kalmıştır. Sulu fazdaki konsantrasyon artışı, toplam boya konsantrasyonundaki artışa kıyasla daha düşük olmakla birlikte (\%0.2 pektin konsantrasyonunda değişen boya konsantrasyonlarının regresyon analizine bağlı olarak yaklaşık \%64), sulu konsantrasyon sisteme katılan boya konsantrasyonu ile artmıştır. Sonuç olarak, boya artan miktarlarda sulu fazda kalmaktadır. Boyanın önemli bir bölümü ise, jel matrisinde enkapsüle edilmiş ve bu durum, jel matrisinin boya bağlama kapasitesinin yüksek olduğunu ortaya koymuştur.

\section{Lipofilik boyanın enkapsülasyon verimi}

Metil kırmızısı, soya yağı içerisinde çözünür hale getirildi (100 veya 500 ppm) ve \%10 su içinde yağ emülsiyonları hazırlamak için ön karışım, emülgatör (\%2 Tween 20) varlığında homojenize edildi. Daha sonra emülsiyonlar pektin dispersiyonlarıyla karıştırıldı ve karışımlar $\mathrm{CaCl}_{2}$ çözeltilerine $(0.2 \mathrm{M})$ damlatıldığında emülsiyon jeli boncukları hazırlanmış oldu. ilk olarak, jel boncuklar, damlacık salınımını izlemek için kırmızı boya eklenmeden hazırlandı ve zamana bağlı olarak yağ damlacıklarının salınımı takip edildi. Yağ damlacıklarının salınım derecesi oldukça düşüktü ve salınımın absorbans değerleri (metil kırmızısı için $410 \mathrm{~nm}$ ) üzerindeki etkisi istatistiksel olarak anlamlı bulunmadı $(P>0.05)$.

Lipofilik boyanın enkapsülasyon verimi (\% EV) 14 gün boyunca izlendi (Şekil 2). Hidrofilik boyadaki duruma benzer şekilde, 100 ppm boya içeren numunelerde \% 0.4 pektin içeren boncuklar için \%EV değeri, \% 0.2 pektin içeren boncuklardan daha yüksek bulundu (Şekil 2A). Deneyin başında nispeten yüksek bir enkapsülasyon etkinliği verini gözlemlendi ve deney sırasında genellikle düşük miktarlarda salınım gözlendi. $\mathrm{t}=0$ 'da $\% 0.4$ ve $\% 0.2$ emülsiyon jellerinin (100 ppm boya için) enkapsülasyon verimi sırasıyla \%99 ve $\% 73$ iken, 2 haftalık depolama sonrasında nihai \%EV değerleri \% 94 ve 64 olarak hesap edildi. Bütün durumlarda, $\% 0.4$ pektin numuneleri, kırmızı boya sızıntısına karşı daha dirençli bulundu.

Benzer şekilde, 500 ppm'lik bir boya konsantrasyonunda metil kırmızısı yüklü emülsiyon hidrojelleri hazırlandı (Şekil 2B). Boncuklardan sızan boya miktarı genellikle oldukça sınırlıydı. Enkapsülasyon verimi yaklaşık olarak ve sırasıyla \% 0.4 ve $\% 0.2$ pektin numuneleri için \%99 ve \% 94 olarak belirlendi. 

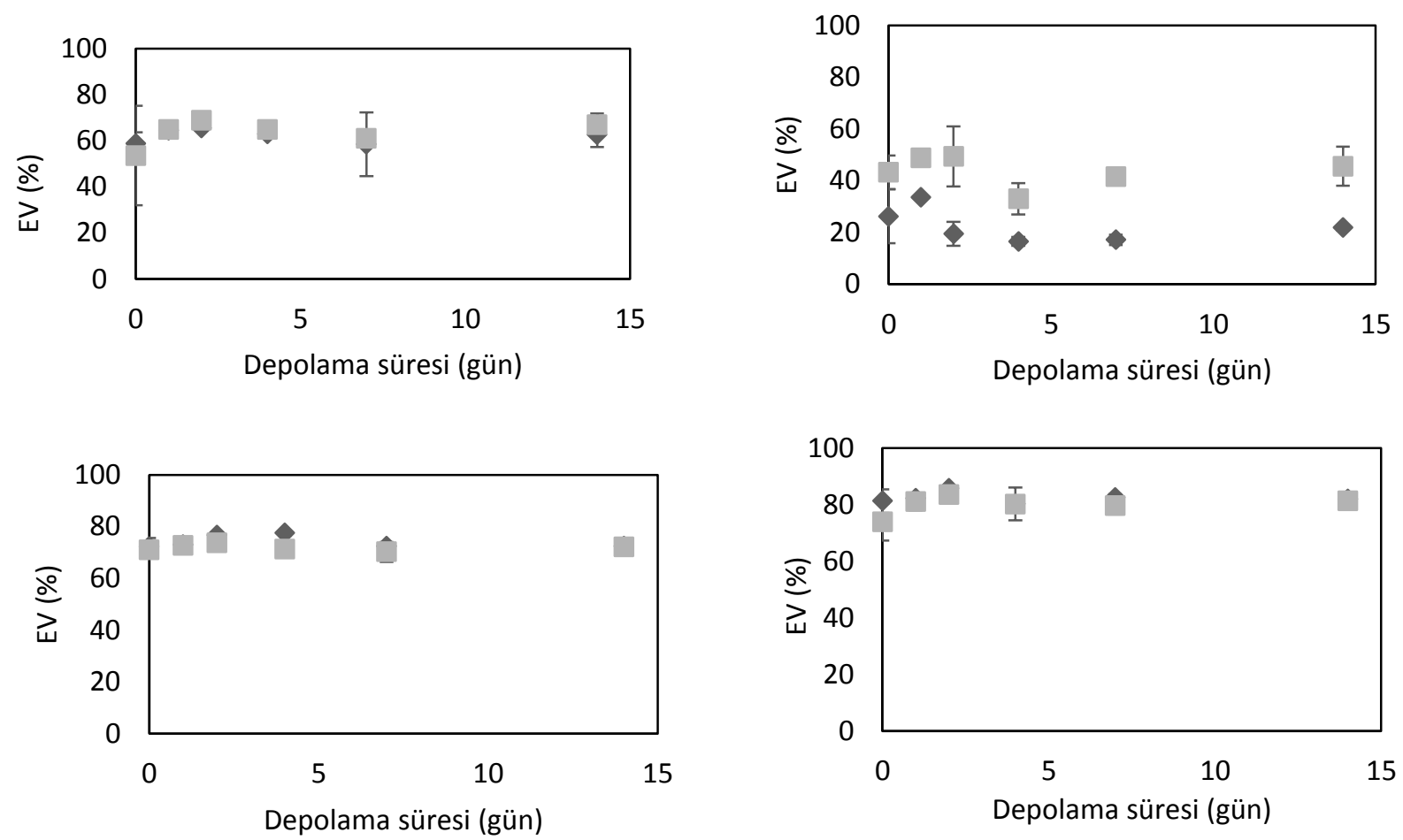

Şekil 1. \% 0.2 (४) ve \% 0.4 (অ) pektin hidrojellerinin (A) 50 ppm, (B) 100 ppm, (C) 200 ppm ve (D) 500 ppm'lik Ponceau $\mathrm{S}$ konsantrasyonlarında enkapsülasyon verimi (\%EV) değerleri ve bu değerlerin zamana bağlı değişimi.

Figure 1. Encapsulation efficiency (\%EE) of Ponceau S in \% $0.2(\diamond)$ or \% 0.4 ( $\mathbf{a})$ pectin hydrogels at a dye concentration level of (A) $50 \mathrm{ppm}$, (B) $100 \mathrm{ppm}$, (C) $200 \mathrm{ppm}$ or (D) $500 \mathrm{ppm}$ and its time dependence.

Buna ek olarak, enkapsüle edilen boya miktarı, $\mathrm{t}=0$ 'da ve 2 haftalık depolamadan sonra zamanın ve boya: pektin oranının ( $\mathrm{mg}$ / $\mathrm{mg}$ ) bir fonksiyonu olarak değerlendirildi (Çizelge 1).

Hidrofilik

boya enkapsülasyonunda da gözlendiği gibi, boncuklarda enkapsüle edilmiş boya içeriği sistemdeki boya miktarı ile arttı. Enkapsüle edilen miktar, depolama süresiyle zayıf bir şekilde ilişkiliydi; bu durum da sistemin kararlılığına işaret etmektedir. Emülsiyon hidrojellerinin lipofilik moleküller için uygun bir teslimat sistemi oluşturduğu söylenebilir. Dolayısıyla, bu çalışmada, hem lipofilik hem de hidrofilik boyaların pektin hidrojellerinde enkapsüle edilebileceği bulgulanmıştır. Grubumuzun önceki çalışmalarında ayçiçeği pektini hidrojellerinden anti-karsinojenik özellikleri bulunan fonksiyonel liyofilizatların hazırlanması incelenmiştir (Çakır ve Gülseren, 2017). Fizikokimyasal muameleler (örneğin, ısıtma, soğutma, pH değişikliği) veya enzimatik hidroliz yöntemleri ile çeşitli teknik veya biyolojik özellikleri bulunan yenilikçi pektin matrislerinin üretilmesi ya da bu malzemelerin başka duvar malzemeleri ile kaplanması (örneğin, gun arabik, maltodekstrin, vakslar vs.) yoluyla farklı koşullarda dayanımı iyileştirilmiş toz ya da sıvı boya formülasyonları üretmenin mümkün olabileceği anlaşılmaktadır. Dolayısıyla oluşturulabilecek pektin matrislerinin gıda, kozmetik, eczacılık vb. birçok alanda kullanım sahalarının geliştirilmesi mümkün olabilecektir. 
Çizelge 1. Pektin hidrojelleri veya emülsiyon jellerinde gerçekleşen Ponceau S veya metil kırmızı enkapsülasyonu miktarı (ppm). Enkapsüle edilen miktarlar (ppm) pektin konsantrasyonu, boya: pektin oranı $(\mathrm{mg} / \mathrm{mg})$ ve zamana bağlı olarak belirlenmiştir. Bütün durumlarda standard sapma $<1 \%$ olarak hesap edilmiştir.

Table 1. Extent of Ponceau S or methyl red encapsulation $(\mathrm{ppm})$ in pectin hydrogels or emulsion hydrogels. Pectin concentration, dye: pectin ratio $\left(\mathrm{mg} . \mathrm{mg}^{-1}\right)$ and time dependence of encapsulated dye concentration (ppm) were listed. Standard deviation was found to be $<1 \%$ in all cases.

\begin{tabular}{|c|c|c|c|c|c|c|}
\hline \multirow[b]{2}{*}{$\begin{array}{l}\text { Pektin konsantrasyonu } \\
\text { (\%) } \\
\text { Pectin concentration (\%) }\end{array}$} & \multicolumn{3}{|c|}{$\begin{array}{l}\text { Ponceau S } \\
\text { Ponceau S }\end{array}$} & \multicolumn{3}{|c|}{$\begin{array}{l}\text { Metil kırmızısı } \\
\text { Methly Red }\end{array}$} \\
\hline & $\begin{array}{l}\text { Boya:pektin } \\
\text { oranı } \\
\left(\mathrm{mg} \cdot \mathrm{mg}^{-1}\right) \\
\text { Dye:pectin } \\
\text { ratio } \\
\left(\mathrm{mg}^{-1} \mathrm{mg}^{-1}\right)\end{array}$ & $\begin{array}{c}\text { Enkapsüle } \\
\text { edilen miktar } \\
\text { (ppm) } \\
\mathrm{t}=0 \\
\text { Extent of } \\
\text { Encapsulation } \\
\text { (ppm) } \\
t=0\end{array}$ & $\begin{array}{c}\text { Enkapsüle } \\
\text { edilen } \\
\text { miktar (ppm) } \\
\mathrm{t}=2 \text { hafta } \\
\text { Extent of } \\
\text { Encapsulation } \\
\text { (ppm) } \\
t=2 \text { weeks }\end{array}$ & $\begin{array}{l}\text { Boya:pektin } \\
\text { oranı } \\
\left(\mathrm{mg} \cdot \mathrm{mg}^{-1}\right) \\
\text { Dye:pectin } \\
\text { ratio } \\
\left(\mathrm{mg}^{-1} \mathrm{mg}^{-1}\right)\end{array}$ & $\begin{array}{c}\text { Enkapsüle } \\
\text { edilen } \\
\text { miktar (ppm) } \\
\mathrm{t}=0 \\
\text { Extent of } \\
\text { encapsulation } \\
\text { (ppm) } \\
t=0\end{array}$ & $\begin{array}{c}\text { Enkapsüle } \\
\text { edilen } \\
\text { miktar (ppm) } \\
\mathrm{t}=2 \text { hafta } \\
\text { Extent of } \\
\text { Encapsulation } \\
\text { (ppm) } \\
t=2 \text { weeks }\end{array}$ \\
\hline \multirow{4}{*}{0.2} & 0.25 & 13.1 & 10.9 & & & \\
\hline & 0.5 & 58.9 & 62.7 & 0.05 & 73.2 & 64.1 \\
\hline & 1 & 144.6 & 144.8 & 0.25 & 470.4 & 464.4 \\
\hline & 2.5 & 406.2 & 409.8 & & & \\
\hline \multirow{4}{*}{0.4} & 0.125 & 21.6 & 22.8 & & & \\
\hline & 0.25 & 53.6 & 66.9 & 0.025 & 99.6 & 94.3 \\
\hline & 0.5 & 141.9 & 144.2 & 0.04 & 496.4 & 485.9 \\
\hline & 1.25 & 369 & 406.5 & & & \\
\hline
\end{tabular}
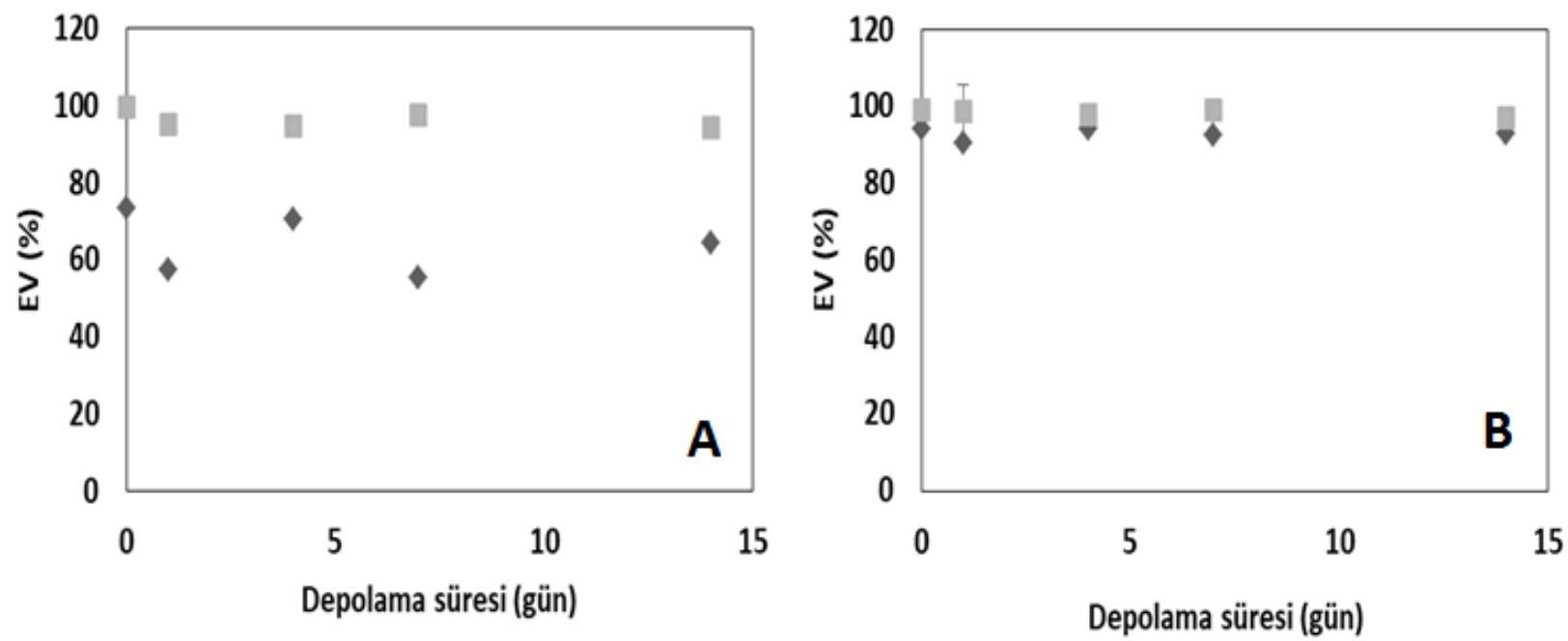

Şekil 2. \% $0.2(\bullet)$ ve \% 0.4 (घ) pektin içeren emülsiyon hidrojellerinin (A) 100 ppm ve (B) 500 ppm'lik metil kırmızıSı konsantrasyonlarında enkapsülasyon verimi (\%EV) değerleri ve bu değerlerin zamana bağlı değişimi.

Figure 2. Encapsulation efficiency (\%EE) of methyl red in \% 0.2 ( ) or \% 0.4 ( $\square$ ) pectin containing emulsion hydrogels at a dye concentration level of (A) 100 ppm, or (D) 500 ppm and its time dependence.

\section{Sonuçlar}

Bu çalışmada, ayçiçeği pektini bazlı hidrojel ve emülsiyon hidrojellerinin kırmızı boyar madde enkapsülasyon özellikleri araştırılmıştır. Enkapsülasyon verimi, genellikle boya ve pektin konsantrasyonları ile artmıştır. Enkapsüle edilmiş moleküllerin çözünürlükleri ve polariteleri, bu moleküllerin pektin matrislerinden salınım özelliklerini etkilemektedir. Örneklerin büyük çoğunluğu 2 haftalık depolamada sürecinde kırmızı boyar maddelerin stabilitesini önemli ölçüde korumayı başarmıştır. Bu bağlamda, ayçiçeği 
pektini renklendiricilerin stabilizasyonu için yararlı bir matris haline gelmektedir. Ayçiçeği pektini, teknik açıdan ve biyolojik açıdan değerli moleküllerin kontrollü salınım ajanı ve taşıyıcısı olma potansiyelini taşımaktadır. Buna ek olarak tekstil ve çevre mühendisliği uygulamalarında, ayçiçeği pektininin renk açıcı ve detoksifikasyon adsorbenti olarak kullanılma potansiyeli vardır. Hem hidrofilik hem de lipofilik molekülleri taşıyabilme özelliği, ayçiçeği pektini jellerinin işlevselliğini arttırmaktadır. Halihazırda bu değerli tarımsal kaynağımızın katma değerlendirilmesi bağlamında ekibimiz fonksiyonel liyofilizatların üretimi ve gıda uygulamalarında değerlendirilmesi alanlarında çalışmaktadır.

\section{Ekler}

$\mathrm{Bu}$ çalışma, TAGEM Ar-Ge Destek Programı'ndan alınan proje desteği (Proje No.TAGEM-14/Ar-Ge/27) ile yürütülmüştür. $\mathrm{Bu}$ çalışma lisansüstü tezlerden üretilmemiştir ve abstract olarak kongre ve sempozyumlarda sunulmamıştır.

\section{Kaynaklar}

Al-Amoudi, M.S., Salman, M., Al-Majthoub, M.M., Adam, A.M.A., Alshanbari, N.A., Refat, M.S., 2015. Spectral studies to increase the efficiency and stability of laser dyes by charge-transfer reactions for using in solar cells: charge-transfer complexes of ponceau $s$ with p-chloranil, chloranilic and picric acids. Research on Chemical Intermediates, 41(5): 3089-3108.

Anthony, C.Y., Chen, H., Chan, D., Agmon, G., Stapleton, L.M., Sevit, A.M. vd. 2016. Scalable manufacturing of biomimetic moldable hydrogels for industrial applications. Proceedings of the National Academy of Sciences of the USA, 201618156.

Arad, S.M., Yaron, A., 1992. Natural pigments from red microalgae for use in foods and cosmetics. Trends in Food Science and Technology, 3: 92-97.
Ashford, M., Fell, J., Attwood, D., Sharma, H., Woodhead, P., 1994. Studies on pectin formulations for colonic drug delivery. Journal of Controlled Release, 30: 225-232.

Chan, E.S., Lee, B.B., Ravindra, P., Denis, P., 2009. Prediction models for shape and size of $\mathrm{Ca}$ alginate macrobeads produced through extrusion-dripping method. Journal of Colloid and Interface Science, 338(1): 63-72.

Clarke, H.T., Kirner, W.R., 1941. Methyl red. Organic Syntheses, 47.

Çakır, B., Gülseren, ì., 2017. 5-Fluorouracil release from sunflower pectin hydrogels in simulated intestinal medium and its corresponding anticarcinogenic activity. International Journal of Pharmaceutical Research, 9(2): 95-98.

Çakır, B., Gülseren, İ., 2017. Dissolution kinetics of polyphenol bearing calcium pectate hydrogels in simulated gastric or intestinal media and their anti-carcinogenic capacities. Food Hydrocolloids, 70: 69-75.

Dufosse, L., Fouillaud, M., Caro, Y., Mapari, S.A., Sutthiwong, N., 2014. Filamentous fungi are large-scale producers of pigments and colorants for the food industry. Current Opinion in Biotechnology, 26:56-61.

Filippidi, E., Patel, A.R., Bouwens, E.C.M., Voudouris, P., Velikov, K.P., 2014. All-natural oil-filled microcapsules from water-insoluble proteins. Advanced Functional Materials, 24: 5962-68.

Glibowski, P., 2009. Rheological properties and structure of inulin-whey protein gels. International Dairy Journal, 19(8): 443449.

Hoffman, A.S., 2002. Hydrogels for biomedical applications. Advanced Drug Delivery Reviews, 54: 3-12.

Iglesias, M.T., Lozano, J.E., 2004. Extraction and characterization of sunflower pectin. Journal of Food Engineering, 62: 215-223.

Matalanis, A., Jones, O.G., McClements, D.J., 2011. Structured biopolymer-based delivery systems for encapsulation, protection and release of lipophilic compounds. Food Hydrocolloids, 25: 1865-80.

McClements, D.J., Decker, E.A., Park, Y., Weiss, J., 2009. Structural design principles for delivery of bioactive components in nutraceuticals and functional foods. Critical Reviews in Food Science and Nutrition, 49: 577-606.

McClements, D.J., Decker, E.A., Weiss, J., 2007. Emulsion based delivery systems for lipophilic bioactive components. Journal of Food Science, 72: R109-R124.

Miyamoto, A., Chang, K.C., 1992. Extraction and physicochemical characterization of pectin from 
sunflower head residues. Journal of Food Science, 57: 1439-43.

Peppas, N.A., Langer, R. (1994). New challenges in biomaterials. Science, 263: 1715-20.

Rubinstein, A., Radai, R., Ezra, M., Pathak, S., Rokem, J.S., 1993. In vitro evaluation of calcium pectinate: a potential colon-specific drug delivery carrier. Pharmaceutical Research, 10: 258-263.

Sahari, M.A., Akbarian, A.M., Hameedi, M., 2003. Effect of variety and acid washing method on extraction yield and quality of sunflower head pectin. Food Chemistry, 83: 43-47.

Shi, X.Q., Chang, K.C., Schwarz, J.G., Wiesenborn, D.P., Shih, M.C., 1996. Optimizing pectin extraction from sunflower heads by alkaline washing. Bioresource Technology, 58: 291-297.

Sowbhagya, H.B., Chitra, V.N., 2010. Enzyme-assisted extraction of flavorings and colorants from plant materials. Critical Reviews in Food Science and Nutrition, 50(2): 146-161.

Sriamornsak, P., Thirawong, N., Puttipipatkhachorn, S.,
2005. Emulsion gel beads of calcium pectinate capable of floating on the gastric fluid: effect of some additives hardening agent or coating on release behavior of metronidazole. European Journal of Pharmaceutical Sciences, 24: 363373.

Wang, W., Liu, X.D., Xie, Y.B., Zhang, H., Yu, W.T., Xiong, Y., Xie, W.Y., Ma, X.J., 2006. Microencapsulation using natural polysaccharides for drug delivery and cell implantation. Journal of Materials Chemistry, 16: 32-52.

Zhang, Y., Zhong, Q., 2013. Encapsulation of bixin in sodium caseinate to deliver the colorant in transparent dispersions. Food Hydrocolloids, 33(1): 1-9.

Zeeb, B., Gibis, M., Fischer, L., Weiss, J., 2012. Crosslinking of interfacial layers in multilayered oil-in-water emulsions using laccase: characterization and pH-stability. Food Hydrocolloids, 27: 126-136. 